\title{
Productivity evaluation of lotic and lentic water body in Himachal Pradesh, India
}

\begin{abstract}
The present study discusses the Primary Productivity of lotic and lentic water. The Light and Dark bottle method are used to measure primary production. The primary productivity helps to determine the trophic level of various aquatic systems. The primary productivity of any aquatic ecosystem depends on the planktonic biodiversity. Estimation of primary productivity of a water body helps to assess its carrying capacity for a biological population which sustain in it by the respiration. It is the most important of all biological phenomena on which the entire diverse life depends directly or indirectly. The present study was done to estimate the primary productivity of lotic water and lentic water. The results showed that in Beas River, the NPP, GPP, Respiration and Gross Photosynthesis were $31.25 \mathrm{mgL} \mathrm{m}^{-1} \mathrm{~h}^{-1}$, $125 \mathrm{mgL} \mathrm{m}^{-1} \mathrm{~h}^{-1}, 112.50 \mathrm{mgL} \mathrm{m}^{-1} \mathrm{~h}^{-1}$, and $0.40 \mathrm{mgL} \mathrm{m}^{-1} \mathrm{~h}^{-1}$, respectively. Whereas, in the Ravi River these were $31.25 \mathrm{mgL} \mathrm{m}^{-1} \mathrm{~h}^{-1}, 52.08 \mathrm{mgL} \mathrm{m}^{-1} \mathrm{~h}^{-1}, 25.01 \mathrm{mgL} \mathrm{m}^{-1} \mathrm{~h}^{-1}, 0.166 \mathrm{mgL} \mathrm{m}^{-1} \mathrm{~h}$ ${ }^{1}$, respectively. In case of another two ponds, the NPP, GPP, Respiration and Gross Photosynthesis were $50 \mathrm{mgL} \mathrm{m}^{-1} \mathrm{~h}^{-1}, 112.50 \mathrm{mgL} \mathrm{m}^{-1} \mathrm{~h}^{-1}, 75 \mathrm{mgL} \mathrm{m}^{-1} \mathrm{~h}^{-1}, 0.36 \mathrm{mgL} \mathrm{m}^{-1} \mathrm{~h}^{-1}$ and $62.50 \mathrm{mgL} \mathrm{m}^{-1} \mathrm{~h}^{-1}, 114.61 \mathrm{mgL} \mathrm{m}^{-1} \mathrm{~h}^{-1}, 62.51 \mathrm{mgL} \mathrm{m}^{-1} \mathrm{~h}^{-1}, 0.36 \mathrm{mg} \mathrm{m}^{-1} \mathrm{~h}^{-1}$, respectively. In the two rivers, it was found that NPP level was in same but GPP and respiration rate were higher in the Beas River water. It shows that the Beas River has the highest rate of photosynthesis as there is the highest number of primary producers. Both the pond has the high value of NPP than river water. However, the highest value of NPP was recorded in lentic water and lowest NPP was recorded in lotic water. The main focus of the study was to estimate the Net Primary Productivity for analyzing the water quality and find the pollution level due to increased anthropogenic activities.
\end{abstract}

Keywords: beas river, himachal pradesh, lentic, lotic, pond, productivity
Volume 3 Issue 5 - 2018

\author{
Pratibha Sharma,Arup Giri \\ Department of Life Sciences, Arni University, India
}

Correspondence: Arup Giri, M.Sc., Ph.D,Assistant Professor Department of Life Sciences, Arni University, Kathgarh, Indora, H.P.-I7640I, India, Te +91 9646919386 Email arupsatadal@gmail.com

Received: July 28, 2018| Published: September 06, 2018

\section{Introduction}

Water is very important for the life of the organism and is most essential for living organism. There is a large number of aquatic organisms such as microscopic planktons and large aquatic animal which lives inside water. Water is present in a large amount on earth but very few are usable, no one can live without water. ${ }^{1-3}$ It is also called as the liquid of life and universal solvent because of its importance in the life of all living organism. Now a day, in both lentic and lotic water systems are getting polluted after mixing and contaminated with the discharge of domestic and industrial effluent wastes, leakage from water tanks, marine dumping, radioactive waste and atmospheric deposition. ${ }^{4-8}$ A major source of water pollution is like domestic sewage, industrialization, population growth, pesticides and fertilizer, plastic and polythene bags, urbanization and weak management system of governmental authority. ${ }^{9-11}$ The researcher found that 75 to $80 \%$ of water pollution is due to the domestic sewage. ${ }^{12}$ Due to direct discharge of domestic sewage into the river water system, rivers are breaking down with a high load of pollutants like toxicants, solid waste, plastic litters, and bacterial contaminants. All these factors or contaminants caused the deterioration of lotic and lentic water system. Industry caused $25 \%$ pollution to the water system because of the high level of toxic metals. ${ }^{13}$

Water scarcity throughout the globe is a current concern. Due to poor water security, $80 \%$ population in the world is facing a severe problem for clean water. ${ }^{14}$ Deteriorated water is now causing $80 \%$ of disease in the earth human population. ${ }^{15}$ Unhygienic and poor quality of water occurring deaths about $3.1 \%$ and $50 \%$ is the child who are most prone to diarrhea. ${ }^{16}$ In Himachal Pradesh, river- like Beas, Ravi, Satluj are also affected by the presence of cadmium, lead, siltation, domestic \& municipal sewage, industrial sewage and surface run-off that affect the water quality directly or indirectly (Table 1$).{ }^{17,18}$

The freshwater bodies are divided into three categories i.e. Lentic, Lotic, and Wetland. Lentic or standing water include lakes and ponds. Lotic or running water includes springs, streams, and rivers. Wetland includes marshes and swamps, where water levels frequently rises and fall, seasonally as well as annually. ${ }^{28}$ The main source of water in India is river water. In India, there are many rivers which play an important part in the life of Indian people. The river system provides water for irrigation and all other purposes. In Hindu mythology, rivers play an important role and Hindus considered them holy in the country ${ }^{29}$. Indus, Tapti, Brahmaputra, Narmada, Krishna, Godavari and Mahanadi are seven major rivers in India. In Himachal Pradesh, there are main five rivers: The Chenab, The Ravi, The Beas, The Sutlej, and The Yamuna. Himachal provides water to the Indus and Ganges basins (Table 2) ${ }^{30,31}$ A pond is standing water body which is smaller than lakes and either natural or artificial. Ponds may be seasonal with the lifespan of few weeks and months, or perennial with age of several hundred years. ${ }^{28}$ Ponds contain water with marsh and aquatic plants and animals. ${ }^{32-34}$

Ponds are frequently human- constructed. The ponds mainly consist of three zones:

a. Littoral zone (a belt close to shoreline, light reaching the bottom, supporting rooted plants),

b. Limnetic zone (light intensity is adequate and planktons are the dominant biota) and

c. Profundal zone (light inadequate or absent, only heterotrophs occur). ${ }^{28}$ 
Table I Review of water quality and human health

\begin{tabular}{|c|c|c|}
\hline SI. no. & Name of the researcher & Effects of polluted water \\
\hline I. & Juneja et al. ${ }^{19}$ & $\begin{array}{l}\text { Toxins in industrial waste caused on immune system break down, reproductive problem, cholera, } \\
\text { typhoid fever etc. }\end{array}$ \\
\hline 2. & Nel et al. ${ }^{20}$ & Fecal pollution in water caused many waterborne infectious diseases \\
\hline 3. & Ullah 21 & $\begin{array}{l}\text { Polluted water fetal for human health as it stimulated respiratory disease, cancer, diarrheal disease, } \\
\text { neurological disorder and cardiovascular disease. }\end{array}$ \\
\hline 4. & Krishnan et al..$^{22}$ & Nitrogenous chemicals in the water system are responsible for cancer and blue baby syndrome. \\
\hline 5. & Currie et al. ${ }^{23}$ & $\begin{array}{l}\text { Pregnant women are most affected by the polluted water which leads to an increased rate of low } \\
\text { birth weight. }\end{array}$ \\
\hline 6. & Khan et al. ${ }^{24}$ & $\begin{array}{l}\text { Crop production and food chain in the ecosystem got hampered due to the deteriorated type of } \\
\text { water quality. }\end{array}$ \\
\hline 7. & Ahmed et al. ${ }^{25}$ & $\begin{array}{l}\text { High level of iron in lentic and lotic water system caused the effect on fish population due to defective } \\
\text { function of gills. }\end{array}$ \\
\hline 8. & Salem et al. ${ }^{26}$ & High level of toxic metals leads to hair loss, liver cirrhosis, and renal failure. \\
\hline 9. & Chowdhury et al. ${ }^{27}$ & Metal contaminated water leads to neural disorder \\
\hline
\end{tabular}

Table 2 The list of rivers flowing in Himachal Pradesh, India

\begin{tabular}{|c|c|c|c|}
\hline $\begin{array}{l}\text { Name of } \\
\text { rivers }\end{array}$ & Name of origin & Length in H.P. & Tributaries \\
\hline Chenab & $\begin{array}{l}\text { Chandra and Bhaga at Tandi, in } \\
\text { Lahaul }\end{array}$ & $122 \mathrm{Km}$ & $\begin{array}{l}\text { Chandra, Bhaga, BhutNallah, Maru, Jammu Tawi, DoaraNullah I\&2, HalseNallah, } \\
\text { BhimberNullah, PalkhuNullah, and BhudiNullah }\end{array}$ \\
\hline Ravi & Bara Banghal, Kangra district & $158 \mathrm{Km}$ & The Budhil,TundahanBeljedi, Saho and ChirchindNala \\
\hline Beas & $\begin{array}{l}\text { The PirPanjal range near The } \\
\text { Rohtang Pass }\end{array}$ & $256 \mathrm{Km}$ & $\begin{array}{l}\text { The Parbati, The Hurla, The Sainj, The Uhl, The Suheti, The Luni, The Banganga and The } \\
\text { Chaki. }\end{array}$ \\
\hline Satluj & Rakas Lake & $320 \mathrm{Km}$ & $\begin{array}{l}\text { The Spiti,The Ropa, The Taiti, The Kashang, The Mulgaon, The Yula, The Wanger, The } \\
\text { Throng, The Rupi,The Tirung, The Gayathing, The Baspa, The Duling and The Soldang }\end{array}$ \\
\hline Yamuna & $\begin{array}{l}\text { Yamunotri in Uttarkashi District, } \\
\text { Uttarakhand }\end{array}$ & $2320 \mathrm{Km}$ & The Tons, The Giri and The Bata \\
\hline
\end{tabular}

Source General outline of rivers in Himachal@webindia I 23

The time is not too far when usable water will be inadequate for the normal living condition of the human population. ${ }^{28}$ Management of freshwater bodies should aim to maintain high productivity level of water bodies with provision for a high rate of harvest of plants and animals for human use. Measurement of primary production or photosynthesis is helpful to understand the tropic status and to assess the fish production potential of the aquatic ecosystem. To estimate the bioactivity of a reservoir it is necessary to determine the magnitude of primary production. The fundamental to understand both water quality and fisheries is the study of primary productivity. Increasing the pattern of productivity helps the population to sustain in a healthy circumstances. ${ }^{35-39}$ the amount of solar energy trapped by the autotrophic organisms is known as production. The amount of solar energy trapped by the autotrophic organisms in unit time is known as productivity. The amount of plankton present in the water body decides the productivity of that water body. ${ }^{40,41}$

Primary productivity is defined as "the rate at which radiant energy is stored by the photosynthetic and chemosynthetic activity of producer." 42 Primary productivity is the most important biological phenomenon in nature on which the entire diverse array of life depends, either directly or indirectly. Primary producers use inorganic nutrients through the process of photosynthesis to built organic matter. Primary producers need essential nutrients to live and grow such as nitrogen, phosphorus, magnesium, calcium, iron, zinc, etc. in sufficient amount. Phytoplankton, Macrophytes, and Periphyton are the main producer in lake and reservoir. ${ }^{43-45}$ Primary productivity is also marked as Gross primary productivity. This is the total rate of photosynthesis including the organic matter used in respiration during the measurement period. Net primary productivity (NPP) is the rate of storage of organic matter in plant tissue in excess of the respiratory utilization by plants during the measurement period. ${ }^{46}$ Thus, net primary productivity refers to the balance between gross photosynthesis and respiration and other plant losses as death. Primary production in aquatic ecosystems has certain features distinct from that in terrestrial systems. ${ }^{47,48}$

The flow of energy through an ecosystem is a unidirectional process in contrast to nutrients which may be cycled many times. The primary productivity is the root of all food chains and food webs of any ecosystem generating $70 \%$ atmospheric oxygen of the world. It is important to note that the study of productivity now receiving so much attention in ecology and the ecologists interested in ecoenergetics are primarily concerned with the quality of incident solar energy per unit area of the ecosystem and the efficiency with which energy is converted by organisms into other forms (chemical energy). ${ }^{49,50}$ With advances in the concepts of ecology, the more formalized study of 
primary production was undertaken first in aquatic systems, then in terrestrial biomes ${ }^{51-53}$ Productivity is considered as an important driver of diversity. ${ }^{54-56}$ Knapp et al. ${ }^{57}$ compiled long-term NPP data from 11 Long-Term Ecological Research (LTER) sites to assess the controls of means and temporal variation in NPP in North American terrestrial ecosystems. The main aim of productivity measurement of aquatic systems was to get a better understanding of the food chain relationships and of the functioning of the ecosystem. In an aquatic ecosystem, the main source of energy input is primary productivity.
It is directly related to temperature and the available nutrients in the water and soil in relation to other physicochemical factors. ${ }^{50}$ Biological production can be used as an index of trophic status, fisheries potential, productivity and biodiversity of water body (Table $3 \& 4){ }^{58-60}$ The object of the present study was to measure the primary productivity of Lotic and Lentic water. Productivity analysis could provide clues for solving water management problems in the study area.

Table 3 Characteristic features in lakes of different trophic categories ${ }^{80,81}$

\begin{tabular}{|c|c|c|c|c|c|c|c|}
\hline Tropic level & $\begin{array}{l}\text { Primary } \\
\text { productivity }\end{array}$ & $\begin{array}{l}\text { Secchi Disk } \\
\text { depth }\end{array}$ & Chl-a & Algal volume & Total-P & Total-N & Dominant fish \\
\hline Oligotrophic & $<30$ & $>5$ & $<2.5$ & $<0.8$ & $<10$ & $<350$ & Trout, Whitefish \\
\hline Mesotrophic & $25-60$ & 6-Mar & 8-Feb & $0.5-1.9$ & 25-Aug & $300-500$ & Whitefish, Perch \\
\hline Eutrophic & $40-200$ & 4-Jan & Jun-35 & $1.2-2.5$ & $20-100$ & $350-600$ & Perch, Roach \\
\hline Hypertrophic & $130-600$ & $0-2$ & $300-400$ & $2.1-20$ & $>80$ & $>600$ & Roach, Bream \\
\hline
\end{tabular}

Table 4 Classification of lakes into trophic classes based on summer surface mean values ${ }^{82}$

\begin{tabular}{lllll}
\hline Trophic level & Total-P $\left(\mu \mathbf{~ L ~}^{-1}\right)$ & Total-N $\left(\mu \mathbf{~ L}^{-1}\right)$ & Chl-a $\left(\mu \mathbf{~ L}^{-1}\right)$ & Secchi disk depth $(\mathbf{m})$ \\
\hline Oligotrophic & $<10$ & $<350$ & $<3.5$ & $>4$ \\
Mesotrophic & $30-$ Oct & $350-650$ & $3.5-9.0$ & $2-A p r$ \\
Eutrophic & $31-100$ & $651-1200$ & $9.1-25$ & 1 \\
Hypertrophic & $>100$ & $>1200$ & $>25$ & 1 \\
\hline
\end{tabular}

\section{Materials and methods}

\section{Study Area}

India is a developing country, which consists of 29 states and 7 union territories. Himachal Pradesh is the main state of India located in north India. It is situated in the western Himalayas and bordered with Jammu \& Kashmir, Punjab, Haryana, Uttarakhand and Uttar Pradesh. It is situated at a high altitude ranging from 450 meters to over 7,026 meters. It is the most beautiful and hilly state having a number of rivers and natural vegetation. It is a sparsely populated state with different topographical and climatic condition. The Geographical Location of Himachal Pradesh is $30^{\prime}$ '22' 40" North to 33' 12' 40" North latitude and its longitudinal extent is 75' 45' 55' East to 79' 04' 20 " East. Himachal Pradesh occupies an area of 55,673 sq. km. There are five rivers flowing through Himachal Pradesh: The Chenab, The Ravi, The Beas, The Satluj, and The Yamuna. The Beas is the major river system of the Indus basin. After originates in Beas Kund near Rohtang pass, flows in the east-west direction in Himachal Pradesh. Then, it emerges in the plains near Talwara in Hoshiarpur district of Punjab state. The total length of this river is $470 \mathrm{Km}$ and its drainage basin is 20,303 sq. Km. ${ }^{31}$ Pond water is collected from Nurpur situated at District Kangra of Himachal Pradesh. Nurpur is located at $32.3^{\circ} \mathrm{N}$ $75.9^{\circ} \mathrm{E}$. It has an average elevation of 643 meters. It was earlier known by the name of Dhameri.

\section{Experimental design}

Four different sites were selected for the collection of the water sample. Two were Lotic and two were Lentic. Sample collection was done in April month of the year 2018. Water was collected from two ponds, the Ravi River, and Beas River (Figure 1-3). The entire sample has been analyzed by the "Dark and Light Bottle method".

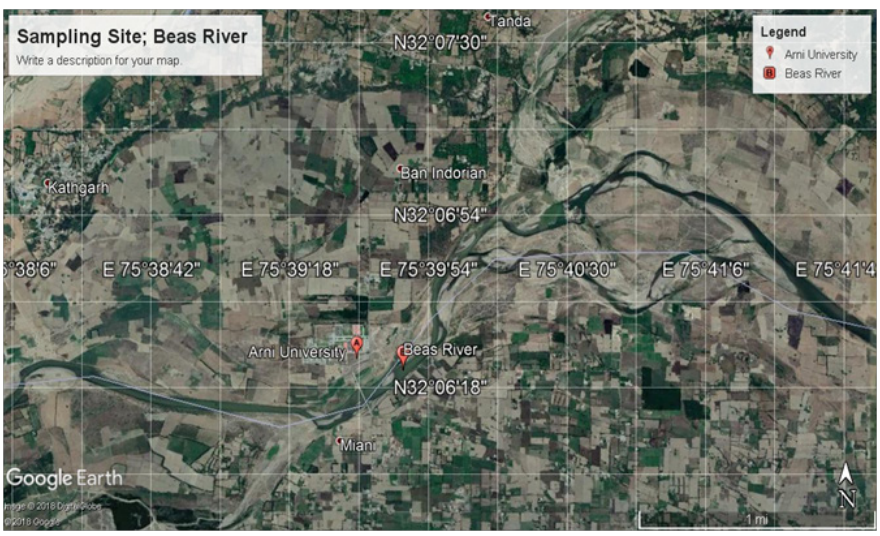

Figure I Location of Beas River sampling site in Himachal.

\section{Sample collection}

The sample of the water for the measurement and comparison of the primary productivity were collected from Ravi River and Beas River, running from the Himachal Pradesh and Punjab State of India. The water sample is collected at latitude $32.49534^{\circ} \mathrm{N}$ and longitude $75.81953^{\circ} \mathrm{E}$ from Ravi River and at latitude $32.10489^{\circ} \mathrm{N}$ and longitude $75.66057^{\circ} \mathrm{E}$ from Beas river. Two samples of Pond water were collected from the pond situated near Nurpur. The Sample 
one is collected at latitude $32.30186^{\circ} \mathrm{N}$, longitude $75.88326^{\circ} \mathrm{E}$ and sample two at latitude $32.30263^{\circ} \mathrm{N}$, longitude $75.91088^{\circ} \mathrm{E}$ by using BOD bottle of $250 \mathrm{ml}$ (Table 5) (Figure 1-3). The sample of water was collected between 9:00 a.m. to 11:00 a.m. The sample of water containing autotrophs is taken from a given depth of river in three sample bottles. One of the bottles is transparent and permitting photosynthesis to take place (light bottle). The other bottle is darkened to stop photosynthesis. Only respiration occurs in this bottle (Dark bottle). The bottles are then incubated for a certain period. Extreme care was taken to see that no air bubble was left inside.

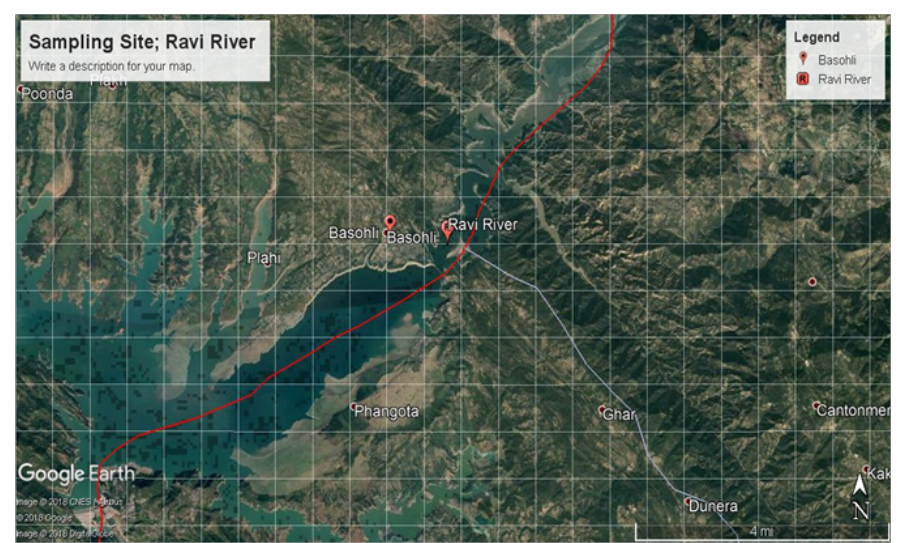

Figure 2 Location of the Ravi River sampling site.

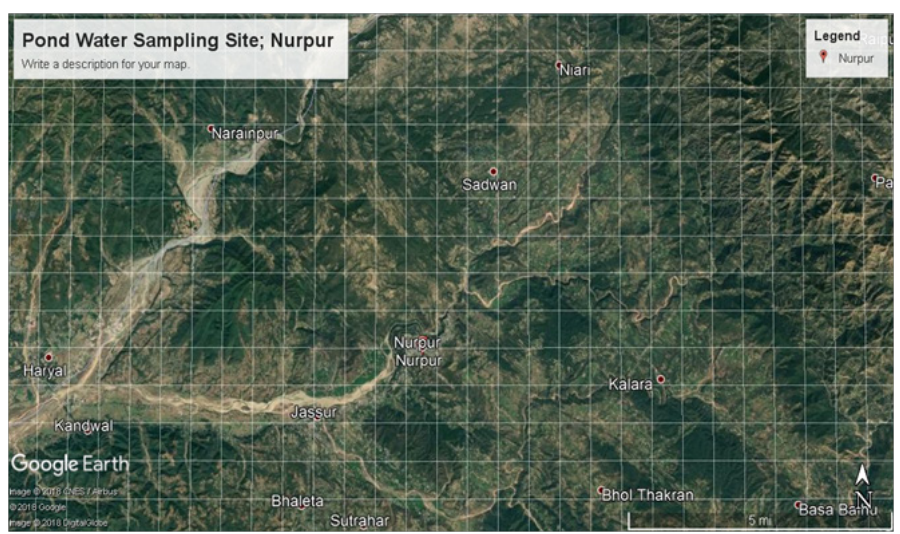

Figure 3 Location of the pond water sampling site.

Table $\mathbf{5}$ The latitude and longitude of various sampling locations

\begin{tabular}{llll}
\hline S. no. & Sampling location & Latitude & Longitude \\
\hline I & Beas river & $32.10489^{\circ} \mathrm{N}$ & $75.66057^{\circ} \mathrm{E}$ \\
2 & Ravi river & $32.49534^{\circ} \mathrm{N}$ & $75.81953^{\circ} \mathrm{E}$ \\
3 & Pond-I & $32.30186^{\circ} \mathrm{N}$ & $75.88326^{\circ} \mathrm{E}$ \\
4 & Pond-2 & $32.30263^{\circ} \mathrm{N}$ & $75.91088^{\circ} \mathrm{E}$ \\
\hline S. no. & Sampling location & Latitude & Longitude \\
\hline I & Beas river & $32.10489^{\circ} \mathrm{N}$ & $75.66057^{\circ} \mathrm{E}$ \\
2 & Ravi river & $32.49534^{\circ} \mathrm{N}$ & $75.81953^{\circ} \mathrm{E}$ \\
3 & Pond-I & $32.30186^{\circ} \mathrm{N}$ & $75.88326^{\circ} \mathrm{E}$ \\
4 & Pond-2 & $32.30263^{\circ} \mathrm{N}$ & $75.91088^{\circ} \mathrm{E}$ \\
\hline
\end{tabular}

\section{Method}

The primary organic production of the river water was determined by 'light and dark bottle method'. ${ }^{61}$ Gaarder and Gran in 1927 first proposed the technique of using light and dark bottles and Winkler's titration to measure the production and consumption of Oxygen. It is the most common method for measuring production and productivity in the aquatic medium. It measures the amount of dissolved (or free) oxygen present in water or wastewater. Dissolved oxygen concentration is defined as the number of millilitres of dissolved gas (oxygen) per litre of water. ${ }^{28}$ In this method, by estimating dissolved oxygen content productivity is measured.

\section{Water productivity calculation}

Gross Primary productivity (GPP), the Net Primary Productivity (NPP) and Respiration were calculated in the following manner:

$$
\begin{aligned}
& \text { Gross Primary Productivity }=\frac{L B-D B}{T} \times \frac{0.375}{P Q} \times 1000 \mathrm{mg} / \mathrm{L} / \mathrm{h} \\
& \text { Net Primary Productivity }=\frac{L B-I B}{T} \times \frac{0.375}{P Q} \times 1000 \mathrm{mg} / \mathrm{L} / \mathrm{h} \\
& \text { Respiration }=\frac{I B-D B}{T} \times \frac{0.375}{P Q} \times 1000 \mathrm{mg} / \mathrm{L} / \mathrm{h}
\end{aligned}
$$

Where:

$$
\begin{aligned}
& \text { LB }=\text { Light bottle, } \\
& \mathrm{DB}=\text { Dark bottle, } \\
& \mathrm{IB}=\text { Initial bottle, } \\
& \mathrm{T}=\text { Time of incubation, } \\
& \mathrm{PQ}=\text { Photosynthesis Quotient }=1.25, \\
& \mathrm{RQ}=\text { Respiratory Quotient }=1 \text { and }
\end{aligned}
$$

The value 0.375 represents a constant to convert Oxygen value to Carbon Value. ${ }^{62}$

\section{Results and discussion}

In the present study, primary productivity of lotic and lentic water have been studied. For the study of lentic water two ponds were selected from Nurpur region and for Lotic water two rivers were selected which flows through Himachal and Punjab. Measurement of Primary production and Photosynthesis is helpful to understand the water quality and trophic status of the aquatic ecosystem. The level of NPP, GPP, and respiration of Beas River, Ravi River, Pond-1, and Pond -2 is given in Table 6 . The results showed that in Beas River, the NPP, GPP, Respiration and Gross Photosynthesis were 31.25 $\mathrm{mgL} \mathrm{m}{ }^{-1} \mathrm{~h}^{-1}, 125 \mathrm{mgL} \mathrm{m}^{-1} \mathrm{~h}^{-1}, 112.50 \mathrm{mgL} \mathrm{m}^{-1} \mathrm{~h}^{-1}, 0.40 \mathrm{mgL} \mathrm{m}^{-1} \mathrm{~h}^{-1}$, respectively. Whereas, in the Ravi River these were $31.25 \mathrm{mgL} \mathrm{m}^{-1} \mathrm{~h}^{-1}$, $52.08 \mathrm{mgL} \mathrm{m}^{-1} \mathrm{~h}^{-1}, 25.01 \mathrm{mgL} \mathrm{m}^{-1} \mathrm{~h}^{-1}, 0.166 \mathrm{mgL} \mathrm{m}^{-1} \mathrm{~h}^{-1}$, respectively. In the case of another two ponds, the NPP, GPP, Respiration and Gross Photosynthesis were $50 \mathrm{mgL} \mathrm{m}^{-1} \mathrm{~h}^{-1}, 112.50 \mathrm{mgL} \mathrm{m}^{-1} \mathrm{~h}^{-1}, 75.00$ $\mathrm{mgL} \mathrm{m}{ }^{-1} \mathrm{~h}^{-1}, 0.36 \mathrm{mgL} \mathrm{m}^{-1} \mathrm{~h}^{-1}$ and $62.50 \mathrm{mgL} \mathrm{m}^{-1} \mathrm{~h}^{-1}, 114.61 \mathrm{mgL} \mathrm{m}^{-1} \mathrm{~h}^{-}$ , $62.51 \mathrm{mgL} \mathrm{m}^{-1} \mathrm{~h}^{-1}, 0.36 \mathrm{mgL} \mathrm{m}^{-1} \mathrm{~h}^{-1}$, respectively. In the two rivers, it was found that NPP level was in same but GPP and respiration rate were higher in the Beas River water. It shows that Beas River has the highest rate of photosynthesis as there is the highest number of primary producers. Both the pond has a high value of NPP than river water. However, the highest value of NPP was recorded in lentic water 
and lowest NPP was recorded in lotic water. There is variation in NPP of water sample at different locations.

Table 6 Values of NPP, GPP, and Respiration of Rivers (Beas and Ravi) and Ponds (I \& 2)

\begin{tabular}{|c|c|c|c|c|c|}
\hline Parameters & Units & $\begin{array}{l}\text { Beas } \\
\text { river }\end{array}$ & $\begin{array}{l}\text { Ravi } \\
\text { river }\end{array}$ & Pond-I & Pond-2 \\
\hline NPP & $\mathrm{mgL} / \mathrm{m}^{3} / \mathrm{h}$ & 31.25 & 31.25 & 50 & 62.5 \\
\hline GPP & $\mathrm{mgL} / \mathrm{m}^{3} / \mathrm{h}$ & 125 & 52.08 & 112.5 & $|14.6|$ \\
\hline Respiration & $\mathrm{mgL} / \mathrm{m}^{3} / \mathrm{h}$ & 112.5 & 25.01 & 75 & 62.51 \\
\hline $\begin{array}{l}\text { Gross } \\
\text { photosynthesis }\end{array}$ & $\mathrm{mgL} / \mathrm{m}^{3} / \mathrm{h}$ & 0.4 & 0.166 & 0.36 & 0.36 \\
\hline
\end{tabular}

The higher value of NPP and GPP is due to penetration of more light intensity which facilitates the higher rate of photosynthesis and ultimately the productivity. The amount of gross production available to the consumer is evaluated by the ratio of the net and gross primary production. ${ }^{63-65}$ Table 7 represents the ratio between the different productivity parameters of lotic and lentic water bodies. The NPP: CR $>1$ could be attributed to the clarity of water as well as suitable temperature which favors abundance of phytoplankton and more photosynthetic activities. It accounts for more penetration of light into the water body. The ratio $<1$ could be on account of less penetration of light into the water due to increased suspended particles resulting in lesser photosynthetic activity and thereby decrease in productivity. Higher production is not governed by a single factor as stated by Singh at al ${ }^{63}$ There are many other factors on which the production of the aquatic ecosystem depends. The rate of production in an aquatic ecosystem is controlled by physicochemical and biological factors. The NPP value for lotic water is $<50 \mathrm{mgL} \mathrm{m}^{-1} \mathrm{~h}^{-1}$, so the nature of lotic water is ultraoligotrophic and NPP value for lentic is $50-300$ $\mathrm{mgL} \mathrm{m}{ }^{-1} \mathrm{~h}^{-1}$, so the nature of lentic water is oligotrophic. ${ }^{66}$ The highest primary productivity is found at lentic water as compared to lotic water. This indicates that the planktonic activity is greater in lentic water. The NPP value for lotic water is $<50$, so the nature of lotic water is ultraoligotrophic and NPP value for lentic is $50-300 \mathrm{mgL} \mathrm{m}^{-1} \mathrm{~h}^{-1}$, so the nature of lentic water is oligotrophic. The low productivity could attribute to the low nutrient levels. Due to the addition of various products in river water the physiochemical parameters of water changes. Many anthropogenic activities lead to the addition of waste into river water. This decreases the primary productivity of the rivers and directly or indirectly affects many aquatic plants and animals. The density or number of aquatic plants and animals decreases. So, it is necessary to treat the water to maintain the primary productivity so that the aquatic plants and the animal can survive in it.

Table 7 Ratio between different productivity parameters of lotic and lentic water bodies

\begin{tabular}{lll}
\hline Rivers & NPP:GPP & NPP:CR \\
\hline Beas & 0.25 & 0.277 \\
Ravi & 0.592 & 1.24 \\
Pond-1 & 0.44 & 0.66 \\
Pond-2 & 0.54 & 0.99
\end{tabular}

Dissolved oxygen (DO) in water affects the oxidation-reduction state of many of the chemical compounds such as nitrate and ammonia, sulfate and sulfite, and ferrous and ferric ions. It is extremely useful in self-purification of water bodies. The reduction in DO level causes the anaerobic condition in water and adversely affects the aquatic biota. ${ }^{67}$ Much of the DO in water comes from the atmosphere due to wind action. Algae and rooted aquatic plants also give out oxygen into water through photosynthesis. ${ }^{68}$ The oxygen content in natural water varies with temperature, salinity, turbulence, the photosynthetic activity of algae and higher plants and the atmospheric pressure. ${ }^{69}$ Variations in the amount of DO occur over a day. This is due to photosynthetic and respiratory processes of algae and higher plants. ${ }^{70}$ The waste and domestic sewage affects the overall condition of the water bodies which is depicted by a decrease in DO, increase in BOD, high ammonia, nitrite and low values of water quality indices (WQI). ${ }^{71}$ The high amount of organic matter undergoing biological degradation is the reason for the depletion of DO in water. ${ }^{72,73}$ The lowering of DO concentration in the water is because of greater input of waste from the different type of anthropogenic activities. Low nutrient levels and high turbidity seems to be due to low productivity. ${ }^{74}$ The decrease of oxygen in the dark bottles helps in determination of respiration rate which is given as their carbon equivalents. ${ }^{75-77}$ Water quality water is affected by the wastes from the homes, agricultural runoff and the drains carrying municipal sewage of the cities. According to the Central Pollution Control Board, untreated sewage is responsible for $70 \%$ of the pollution in rivers which results in low DO and high BOD. ${ }^{67,73,78,79}$ According to the present study, ponds seem to have the highest Net primary productivity than the rivers. Low Net Primary Productivity at rivers may be due to the addition of a high amount of wastes. Moreover, domestic waste is added to a high amount to Beas and Ravi Rivers as these are situated near the rural area.

\section{Conclusion}

The highest primary productivity is found at lentic water as compared to lotic water. This indicates that the planktonic activity is greater in lentic water. The NPP value for lotic water is $<50$ $\mathrm{mgL} \mathrm{m}{ }^{-1} \mathrm{~h}^{-1}$, so the nature of lotic water is ultraoligotrophic and NPP value for lentic is $50-300 \mathrm{mgL} \mathrm{m}^{-1} \mathrm{~h}^{-1}$, so the nature of lentic water is oligotrophic. The low productivity could attribute to the low nutrient levels. Due to the addition of various products in river water the physiochemical parameters of water changes. Many anthropogenic activities lead to the addition of waste into river water. This decreases the primary productivity of the rivers and directly or indirectly affects many aquatic plants and animals. The density or number of aquatic plants and animals decreases. So, it is necessary to treat the water to maintain the primary productivity so that the aquatic plants and an animal can survive in it.

\section{Acknowledgements}

The Authors are thankful to Dr Rajesh Kumar, Head of the Division and Indu Kumari, Research Associate, Life Science Department, Arni University for providing the lab facility.

\section{Conflict of Interest}

The authors declared no potential conflicts of interest with respect to the research, authorship, and/or publication of this article.

\section{References}

1. Trishala KP, Deepak R, Agrawal YK. Bioindicators: the natural indicator of environmental pollution. Frontiers in Life Sci. 2016;9(2):110-118.

2. Kummu M, de Moel H, Ward PJ, et al. How Close Do We Live to Water? A Global Analysis of Population Distance to Freshwater Bodies. PLoS ONE. 2011;6(6):e20578. 
3. Kummu M, Guillaume JHA, de Moel H, et al. The world's road to water scarcity: shortage and stress in the 20th century and pathways towards sustainability. Sci Rep. 2016;6:38495.

4. National Research Council (US) Safe Drinking Water Committee. Drinking Water and Health: Volume 1. Washington (DC): National Academies Press (US); VII, Radioactivity In Drinking Water. 1977.

5. Prăvălie R. Nuclear Weapons Tests and Environmental Consequences: A Global Perspective. Ambio. 2014;43(6):729-744.

6. Profitós HJM, Mouhaman A, Lee S, et al. Muddying the Waters: A New Area of Concern for Drinking Water Contamination in Cameroon. Int $J$ Environ Res Public Health. 2014;11(12):12454-12472.

7. Frisbie SH, Mitchell EJ, Sarkar B. Urgent need to reevaluate the latest World Health Organization guidelines for toxic inorganic substances in drinking water. Environ Health. 2015;14:63.

8. Daniels ME, Smith WA, Jenkins MW. Estimating Cryptosporidium and Giardia disease burdens for children drinking untreated groundwater in a rural population in India. PLoS Neglected Tropical Diseases. 2018;12(1):e0006231.

9. Puri A, Kumar M, Johal E. Solid-waste management in Jalandhar city and its impact on community health. Indian $J$ Occu Environ Med. 2008;12(2):76-81.

10. El-Said GF, Draz SE, El-Sadaawy MM, Moneer AA. Sedimentology, geochemistry, pollution status and ecological risk assessment of some heavy metals in surficial sediments of an Egyptian lagoon connecting to the Mediterranean Sea. J Environ Sci Health A Tox Hazard Subst Environ Eng. 2014; 49(9):1029-1044.

11. Soliman NF, Nasr SM, Okbah MA. Potential ecological risk of heavy metals in sediments from the Mediterranean coast, Egypt. J Environ Health Sci Eng. 2015;13:70.

12. Kamble SM. Water pollution and public health issues in Kolhapur city in Maharashtra. Int J Scient Res Publications. 2014;4(1):1-6.

13. Desai N, Vanitaben. A study on the water pollution based on the environmental problem. Indian J Res. 2014;3(12):95-96.

14. Owa FD. Water pollution: sources, effects, control and management. Mediterranean J Social Sci. 2013;4(8):65-68.

15. Khan N, Hussain ST, Saboor A, et al. Physiochemical investigation of the drinking water sources from Mardan, Khyber Pakhtunkhwa, Pakistan. Int J Physi Sci. 2013;8(33):1661-1671.

16. Pawari MJ, Gawande S. Groundwater pollution \& its consequence. Int J Eng Res Gen Sci. 2015;3(4):773-776.

17. Sharma N, Walia YK. Water Quality Investigation by Physicochemical Parameters of Satluj River (Himachal Pradesh, India). Curr World Environ. 2017;12(1):174-180.

18. Sharma S, Walia YK. Water Quality Assessment of River Beas During Winter Season in Himachal Pradesh, India. Curr World Environ. 2016;11(1):363-371.

19. Juneja T, Chauhdary A. Assessment of water quality and its effect on the health of residents of Jhunjhunu district, Rajasthan: A cross- sectional study. J Public Health and Epidemiology. 2013;5(4):186-191.

20. Nel LH, Markotter W. New and emerging waterborne infectious diseases. Encyclopedia of life support system. Water and health. 2009;1:1-10.

21. Ullah S, Javed MW, Shafique M, et al. An integrated approach for quality assessment of drinking water using GIS: A case study of Lower Dir. $J$ Himalayan Earth Sci. 2014;47(2):163-174.

22. Krishnan S, Indu R. Groundwater contamination in India: Discussing physical processes, health and socio-behavioral dimensions. IWMI-Tata, Water Policy Research Programmes, Anand, India; 2006.

23. Currie J, Joshua GZ, Katherine M, et al. Something in the water: contaminated drinking water and infant health. Canadian J Economics. 2013;46(3):791-810.

24. Khan MA, Ghouri AM. Environmental Pollution: Its effects on life and its remedies. J Arts Sci Commerce. 2011;2(2):276-285.

25. Ahmed T, Scholz F, Al-Faraj W, et al. Water-related impacts of climate change on agriculture and subsequently on public health: A review for generalists with particular reference to Pakistan. Int J Environ Res Public Health. 2013;13:1-16.

26. Salem HM, Eweida EA, Farag A. Heavy metals in drinking water and their environmental impact on human health. ICEHM. 2000:542-556.

27. Chowdhury S, Annabelle K, Klaus FZ. Arsenic contamination of drinking water and mental health. 2015:1-28.

28. Singh JS, Singh SP, Gupta SR. Ecology Environmental Science and Conservation. S. Chand publication \& Company Pvt. Ltd. 2015;435.

29. Agoramoorthy G. Sacred Rivers: their spiritual significance in Hindu religion. J Relig Health. 2015:54(3):1080-1090.

30. Raina S. Endocrinology in the hills of Himachal Pradesh, India. Indian J End Meta. 2012;16(2):316-317.

31. Wikipedia contributors. Rivers in Himachal Pradesh. In Wikipedia. The Free Encyclopedia. 2018.

32. Usio $N$, Imada $M$, Nakagawa $M$, et al. Effects of pond draining on biodiversity and water quality of farm ponds. Conserv Biol. 2013;27(6):1429-38.

33. Lobban CS, Schefter M. Freshwater biodiversity of Guam. 1. Introduction, with new records of ciliates and a heliozoan. Micronesica, 2008;40(12):273-293

34. Wikipedia contributors Pond. The Free Encyclopedia. 2018.

35. Molden D, Sakthivadivel R, Habib Z. Basin-level Use and Productivity of Water: Examples from South Asia. Research Report 49, International Water Management Institute, Colombo, Sri Lanka; 2001.

36. Edgerton MD. Increasing Crop Productivity to Meet Global Needs for Feed, Food, and Fuel. Plant Physiol. 2009;149(1):7-13.

37. Morison JI, Baker N, Mullineaux P, et al. Improving water use in crop production. Philos Trans R Soc Lond B Biol Sci. 2008;363(1491):639658.

38. Babar HT, Raje GB. Primary productivity study of Morawane dam in Ratnagiri district of Maharashtra, India. The Journal of Global Biosci. 2015;4:1430-1438.

39. Mabhaudhi T, Chibarabada T, Modi A. Water-Food-Nutrition-Health Nexus: Linking Water to Improving Food, Nutrition and Health in SubSaharan Africa. Int J Environ Res Public Health. 2016;13(1):107.

40. Guy D. The ecology of the fish pond ecosystem with special reference to Africa. Pergamon press, 1992;220-230.

41. Korhonen JJ, Wang J, Soininen, J. Productivity-Diversity Relationships in Lake Plankton Communities. PLoS ONE. 2011;6(8):e22041.

42. Odum EP. Fundamentals of Ecology. 3rd ed. W.B. Saunders Company, Philadelphia. 1971;1-574.

43. Goldsborough LG, Robinson GGC. Pattern in wetlands. In: Stevenson RJ, Bothwell ML, Lowe RL, editors. Algal ecology: freshwater benthic ecosystems. Academic Press, San Diego. 1996;77-117.

44. Algarte VM, Siqueira T, Landeiro VL, et al. Main predictors of periphyton species richness depend on adherence strategy and cell size. PLoS ONE. 2017;12(7): e0181720.

45. Yan Z, Wang Y, Wu D, et al. Exploration of an urban lake management model to simulate chlorine interference based on the ecological relationships among aquatic species. Sci Rep. 2018;8:8325. 
46. Verma BS, Srivastava SK. Study of Factors Affecting Phytoplankton Primary Productivity in a Pond of Patna, Bihar, India. Nat Environ Pollut Technol Int Quart Sci J. 2015;15:291-296.

47. Shurin JB, Gruner DS, Hillebrand H. All wet or dried up? Real differences between aquatic and terrestrial food webs. Proc Royal Soc B: Biol Sci. 2006;273(1582):1-9.

48. Cebrian J, Shurin JB, Borer ET, et al. Producer Nutritional Quality Controls Ecosystem Trophic Structure. PLoS ONE. 2009;4(3):e4929.

49. Cristescu B, Boyce MS. Focusing Ecological Research for Conservation. Ambio. 2013;42(7):805-815.

50. Kumar A. Studies on Monthly and Seasonal Variations in Primary Productivity of Glacial fed Mountainous Goriganga River in Kumaun Himalaya, Uttarakhand, India. Int Res J Biol Sci. 2015;4:53-56.

51. McIntosh RP. The background of ecology. Cambridge University Press, New York, New York, USA. Review of different Physico Chemical Parameter in water of Indian Rivers and Ponds during summer season, USA; 1985.

52. McNickle GG, Gonzalez-Meler MA, Lynch DJ, et al. The world's biomes and primary production as a triple tragedy of the commons foraging game played among plants. Proc R Soc B Biol Sci. 2016;283(1842):20161993.

53. Malhi Y, Doughty C, Galbraith D. The allocation of ecosystem net primary productivity in tropical forests. Philos Trans $R$ Soc B Biol Sci. 2011;366(1582):3225-3245.

54. Oehri J, Schmid B, Schaepman-Strub G, et al. Biodiversity promotes primary productivity and growing season lengthening at the landscape scale. Proc Nat Academy Sci USA. 2017;114(38):10160-10165.

55. Allan E, Weisser W, Weigelt A, et al. More diverse plant communities have higher functioning over time due to turnover in complementary dominant species. Proc Nat Academy Sci USA. 2011;108(41):17034-17039.

56. Van Ruijven J, Berendse F. Diversity-productivity relationships: Initial effects, long-term patterns, and underlying mechanisms. Proc Nat Academy Sci USA. 2005;102(3):695-700.

57. Knapp AK, Smith MD. Variation among biomes in temporal dynamics of aboveground primary production. Sci. 2001;291:481-484.

58. El-Serehy HA, Abdallah HS, Al-Misned FA, et al. Aquatic ecosystem health and trophic status classification of the Bitter Lakes along the main connecting link between the Red Sea and the Mediterranean. Saudi J Biol Sci. 2018;25(2):204-212.

59. McIntyre PB, Reidy Liermann CA, Revenga C. Linking freshwater fishery management to global food security and biodiversity conservation. Proc Natl Acad Sci U S A. 2016;113(45):12880-12885.

60. Omar WMW. Perspectives on the Use of Algae as Biological Indicators for Monitoring and Protecting Aquatic Environments, with Special Reference to Malaysian Freshwater Ecosystems. Trop Life Sci Res. 2010;21(2):5167.

61. Garder TG, Green HH. Investigation of the production of plankton in the Osio Ford. Rapp. Process-Reunions council pernt. Intern. Exploration. 1927;42:1-48.

62. Thomas PA, Abraham T, Abraham KG. Observation on the primary productivity of Sasthamkotta Lake. In: Alexander KM et al. editors. $J$ Environ Biol Trivandram. 1980;1-7.

63. Singh AK, Singh DK. A comparative study of the phytoplanktonic primary production of river Ganga and pond of Patna (Bihar), India. J Environ Biol. 1999;20:263-270.

64. Yu B, Chen F. The global impact factors of net primary production in different land cover types from 2005 to 2011. Springer Plus. 2016;5(1):1235.
65. Xiao CW, Yuste JC, Janssens IA, et al. Above- and belowground biomass and net primary production in a 73-year-old Scots pine forest. Tree Physiol. 2003;23(8):505-516.

66. Quadros G, Gurav G. Draft report on the Study of Lakes on Mumbai. World Wide Fund for Nature, India; 2009.

67. Naidoo S, Olaniran AO. Treated Wastewater Effluent as a Source of Microbial Pollution of Surface Water Resources. Int J Environ Res Public Health. 2014;11(1):249-270.

68. Pedersen O, Colmer TD, Sand-Jensen K. Underwater Photosynthesis of Submerged Plants - Recent Advances and Methods. Frontiers in Plant Sci. 2013;4:140

69. Mondal M, Goswami S, Ghosh A, et al. Production of biodiesel from microalgae through biological carbon capture: a review. 3 Biotech. 2017;7(2):99.

70. Dahal K, Martyn GD, Alber NA, et al. Coordinated regulation of photosynthetic and respiratory components is necessary to maintain chloroplast energy balance in varied growth conditions. J Exp Bot. 2017;68(3):657-671.

71. Bhatnagar A, Chopra G, Malhotra P. Water quality indices and abiotic characteristics of western Yamuna canal in Yamunanagar, Haryana. $J$ Appl Nat Sci. 2009;1:149-154.

72. Rim-Rukeh A, Ikhifa OG, Okokoyo AP. Effects of agricultural activities on the water quality of Orogodo river, Agbor Nigeria. J Appl Sci Res. 2006;2:256-259.

73. Abdel-Raouf N, Al-Homaidan AA, Ibraheem IBM. Microalgae and wastewater treatment. Saudi J Biol Sci. 2012;19(3):257-275.

74. Ogbuagua DH, Ayoade AA. Estimation of primary production along gradients of the middle course of Imo River in Etche, Nigeria. Int J Biosci. 2011;1:68-73.

75. Rajyalakshmi T, Premswarup TV. Primary productivity in river Godavari India. Indian J Fisheries. 1975;22:205-214.

76. Serret P, Robinson C, Aranguren-Gassis M, et al. Both respiration and photosynthesis determine the scaling of plankton metabolism in the oligotrophic ocean. Nature Communications. 20156;6:6961.

77. Hitchcock GL, Kirkpatrick G, Minnett P, et al. Net community production and dark community respiration in a Karenia brevis(Davis) bloom in West Florida coastal waters, USA. Harmful Algae. 2010;9(4):351-358.

78. Khaiwal R, Ameena M, Monika R, et al. Seasonal variations in physicochemical characteristics of river Yamuna in Haryana and its ecological best designated use. J Environ Monit. 2003;5(3):419-426.

79. Wen Y, Schoups G, van de Giesen N. Organic pollution of rivers: Combined threats of urbanization, livestock farming and global climate change. Sci Rep. 2017;7:43289.

80. OECD. Eutrophication of Waters. Monitoring, Assessment and Control. OECD, Paris, 1982;154.

81. Hakanson L, Boulion VV. Regularities in Primary Production, Secchi Depth and Fish Yield and a New System to Define Trophic and Humic State Indices for Lake Ecosystems. Inte Rev Hydrobiol. 2001;86(1):23-62.

82. Nürnberg GK. Trophic state of clear and colored, soft- and hard water lakes with special consideration of nutrients, anoxia, phytoplankton and fish. J Lake and Reservoir Management. 1996;12(4):432-447. 